\title{
A young man with concurrent acute appendicitis and incarcerated right indirect inguinal hernia
}

\author{
Mohammad Farwana' \\ Reem Farwana ${ }^{2}$ \\ Ikram Nasr ${ }^{3}$ \\ 'King's College London, London, \\ 'University of Birmingham, \\ Birmingham, ${ }^{3}$ Guy's and St Thomas' \\ Hospital, London, UK
}

This article was published in the following Dove Press journal:

International Medical Case Reports Journal

26 April 2016

Number of times this article has been viewed

\section{Dear editor}

We read with great interest the expert opinion of Ditsatham et al $^{1}$ on an extremely interesting case. Ditsatham describes a patient who presented with both appendicitis and an indirect inguinal hernia. There is very little known on the subject of concurrent appendicitis and hernia throughout the literature. There were some aspects to the history that stood out.

The past medical history was particularly revealing. The patient had presented with pectus excavatum, which had been repaired by Nuss procedure. There is little information in the literature on the etiology of pectus excavatum; however, a link between the condition and connective tissue disorders has been made. ${ }^{2}$ One can infer from Redlinger et $\mathrm{al}^{2}$ that if pectus excavatum is exhibited in over two-thirds of Marfan syndrome patients, it may be linked to the connective tissue, specifically collagen. The presence of a collagen abnormality, even one that may not be synonymous with a diagnosis, can still pose certain health problems.

Klinge et $\mathrm{al}^{3}$ present the link between collagen abnormalities and an increased risk of recurrent abdominal hernia. Parallels can be drawn to our patient who presented with a reducible inguinal mass 4 years prior to his described presentation. The risk of such a rare concurrent event may be increased if linked with a connective tissue disorder. Further research should be undertaken in this field to look for a causative relationship.

Conditions with unusual presentation of appendicitis have been described; this paper made reference to a rare condition, Amyand hernia, named after an English surgeon. This is relevant since Amyand hernias are often misdiagnosed as a strangulated hernia, and so, the incidence of possible concurrent appendicitis and hernia is higher than reported. ${ }^{4}$

Concurrent appendicitis and other acute abdomen conditions have also been reported. Eggleston and Afzal ${ }^{5}$ describe a case of concurrent appendicitis and cecal bascule. In the case reported by Ditsatham, interest diverts to link the two conditions. Could the strangulation of appendix secondary to the traction of omentum in the hernia sac cause appendicitis? The rare presentation of these two conditions makes the viability of an observational study difficult.

To conclude, it can be said that this young man may have had a mild underlying collagen abnormality that has led to an increased risk of hernia, thus increasing his
Correspondence: Mohammad Farwana King's College London, Great Maze Pond, London SEI 9RT, UK

Tel +44753055 7933

Email mohammad.farwana@kcl.ac.uk (c) (1) (5) 2016 Farwana et al. This work is published and licensed by Dove Medical Press Limited. The full terms of this license are available at https://www.dovepress.com/terms. cc. ${ }_{\mathrm{BY}} \mathrm{NC}$ php and incorporate the Creative Commons Attribution - Non Commercial (unported, v3.0) License (http://creativecommons.org/licenses/lby-nd/3.0/). By accessing the work you hereby accept the Terms. Non-commercial uses of the work are permitted without any further permission from Dove Medical Press Limited, provided the work is properly attributed. For pou hereby accept the Terms. Non-commercial uses of the work are permitted without any further permission from Dove Medical Press
permission for commercial use of this work, please see paragraphs 4.2 and 5 of our Terms (https://www.dovepress.com/terms.php). 
$0.0009 \%$ risk of developing a concurrent appendicitis and inguinal hernia. The systemic effects of connective tissue disease need to be further explored, with particular attention being paid to the manifestations in the bowel. An important learning point highlighted by this case is that you should always be thorough with your examination and never rule out the possibility of concurrent pathology.

\section{Disclosure}

The authors report no conflicts of interest in this communication.

\section{References}

1. Ditsatham C, Somwangprasert A, Watcharachan K, Wongmaneerung P. A young man with concurrent acute appendicitis and incarcerated right indirect inguinal hernia. Int Med Case Rep J. 2016;9:5-7.
2. Redlinger RE, Rushing GD, Moskowitz AD, et al. Minimally invasive repair of pectus excavatum in patients with Marfan syndrome and marfanoid features. J Pediatr Surg. 2010;45(1):193-199.

3. Klinge U, Binnebösel M, Rosch R, Mertens P. Hernia recurrence as a problem of biology and collagen. J Minim Access Surg. 2006;2(3): $151-154$

4. Cigsar EB, Karadag CA, Dokucu AI. Amyand's hernia: 11 years of experience. J Pediatr Surg. Epub 2015 Nov 24.

5. Eggleston BE, Afzal R. Cecal bascule with concurrent acute appendicitis. Appl Radiol. Available from: http://appliedradiology.com/articles/ cecal-bascule-with-concurrent-acute-appendicitis. Accessed January 7 , 2016.

6. Gaillard F. Caecal bascule. Radiology Reference Article. Radiopaedia. Available from: http://radiopaedia.org/articles/caecal-bascule. Accessed January 7, 2016.

Dove Medical Press encourages responsible, free and frank academic debate. The content of the International Medical Case Reports Journal 'letters to the editor' section does not necessarily represent the views of Dove Medical Press, its officers, agents, employees, related entities or the International Medical Case Reports Journal editors. While all reasonable steps have been taken to confirm the content of each letter, Dove Medical Press accepts no liability in respect of the content of any letter, nor is it responsible for the content and accuracy of any letter to the editor.

\section{Dovepress}

\section{Publish your work in this journal}

The International Medical Case Reports Journal is an international, peer-reviewed open-access journal publishing original case reports from all medical specialties. Previously unpublished medical posters are also accepted relating to any area of clinical or preclinical science. Submissions should not normally exceed 2,000 words or
4 published pages including figures, diagrams and references. The manuscript management system is completely online and includes a very quick and fair peer-review system, which is all easy to use. Visit $\mathrm{http}: / / \mathrm{www}$.dovepress.com/testimonials.php to read real quotes from published authors. 